\title{
QURAISH SHIHAB'S QURANIC EXEGESIS ON INTERRELIGIOUS HARMONY AND ITS RELEVANCE TO THE CONTEMPORARY WESTERN HERMENEUTICS
}

\author{
Abdulloh Fuadi \\ Universitas Islam Negeri (UIN) Mataram \\ Email: abdulloh.fuadi@uinmataram.ac.id
}

\begin{abstract}
This paper discusses Quraish Shihab's Quranic Exegesis and its relevance to the hermeneutics framework of Martin Heidegger and Jurgen Habermas to trace Islamic moderation in Indonesia. The issue of interreligious harmony is the main theme of discussion. The type of library research is used in this research, where data is drawn from books, journal articles, and audio-video files. This paper is divided into three parts. The first part presents Quraish Shihab's qur'anic exegesis on inter-religious harmony, which was delivered at Lentera Hati and written in some of his works. The second part of the paper discusses Heidegger's facticital hermeneutics and Habermas's critical hermeneutics. The third part tries to integrate the qur'anic exegesis of Shihab with the hermeneutics concepts of Heidegger and Habermas. This effort of relevance is divided into two points of analysis. The first point juxtaposes Shihab and Heidegger in existentialist philosophical analysis. The second point juxtaposes Shihab and Habermas in intersubjective communication analysis. The paper shows the stringing network of meaning expressed by Quraish Shihab with contemporary western hermeneutics. Therefore, the paper argues that the religious thought of contemporary Indonesian exegete, M. Quraish Shihab, is relevant to the philosophical thoughts of contemporary philosophers, such as Heidegger and Habermas.
\end{abstract}

Keywords: Quraish Shihab, Marin Heidegger, Jurgen Habermas, Interreligious Harmony

DOI: https://doi.org/10.20414/ujis.v25i1.441

\section{Introduction}

THE SITUATION of contemporary civilization, where the intensity of human relationships around the world is closely intertwined, demands identity management wisely, on the scale of both self and community. Leonard Swidler called the evolution of this 
relationship as a change from the age of monologue to the age of dialogue. ${ }^{1}$ One of identities attached to most of people around the world is religion. Management of religious identity in this contemporary era brings out a new motto: to be religious today is to be interreligious. ${ }^{2}$ A believer can only describe his/her religious identity in relation to the others. The identity image of a religious person relates to his/her interaction with other people having different faith and religion. Relationship with the others is a part of his/her religious identity.

M. Quraish Shihab (b.1944), a contemporary Indonesian qur'anic exegete, describes inter-human relationship of religious identity in pluralistic Indonesian context as inter-religious harmony. Annotations of his works can be traced in several writings. Most of them related to qur'anic studies. Some say that Quraish Shihab is a scholar having a tremendous spirit and effort to integrate Islamic religious messages with contemporary context. $^{3}$

The framework of contemporary civilization, however, has been mixed in such a way by many philosophers, both modern and postmodern. Among the influential philosophers are Martin Heidegger (1889-1976) and Jurgen Habermas (b.1929). The hermeneutics concept of these two figures has contributed in coloring the image of contemporary civilization. Heidegger focused on the concept of self, while Habermas focused on the concept of social relation. Heidegger is remembered by his facticital (faktizitat) hermeneutics, while Habermas is known for

${ }^{1}$ Leonard Swidler and Paul Mojzes, The Study of Religion in an Age of Global Dialogue (Philadelphia: Temple University Press, 2000), 145.

2 J.B. Banawiratma, Dialog Antarumat Beragama - Gagasan dan Praktik di Indonesia (Bandung: Mizan, 2010), 248.

${ }^{3}$ Saifuddin, "Pergeseran Wacana Relasi Gender dalam Kajian Tafsir di Indonesia: Perbandingan Penafsiran 'Abd Al-Rauf Singkel dan M. Quraish Shihab," Mu'adalab: Jurnal Studi Gender dan Anak II, no. 2 (2014); Moh. Cholil, "Relevansi Pemikiran Tafsir Jihad M. Quraish Shihab dalam Tafsir al-Misbah," Maraji: Jurnal Studi Keislaman 1, no. 2 (2015); Chamim Thohari, "Konstruks Pemikiran Quraish Shihab tentang Hukum Jilbab - Kajian Hermeneutika Kritis," Journal Salam 14, no. 1 (2011); Umar Sidiq, "Diskursus Makna Jilbab dalam Surat al-Ahzab Ayat 59 Menurut Ibnu Kathir dan M. Quraish Shihab," Journal Kodifikasia 6, no. 1 (2012). 
his critical hermeneutics. The discussion concerning hermeneutical link between Quraish Shihab and these two philosophers is possible because Quraish Shihab has used several philosophers' thoughts in his various works. There are at least 25 names of philosophers spread on each of his magnum opus qur'anic exegesis volumes, Tafsir al-Misbah. ${ }^{4}$

This research seeks to string up networks of meaning expressed by Quraish Shihab as he talked about inter-religious harmony in a television program, Lentera Hati, aired on Metro TV, with the hermeneutics concept of Heidegger and Habermas. This paper is divided into three parts. The first part presents a Quraish Shihab's talk on interreligious harmony, which is delivered at Lentera Hati on Metro TV. The event which lasted about 30 minutes was divided into two sessions: monologue and dialogue. To find out a deeper Quranic interpretation of the Quraish Shihab on interreligious harmony, the data obtained from the event was supported by data from various works of Quraish Shihab on similar themes. The second part of the paper discusses Heidegger's facticital hermeneutics and Habermas's critical hermeneutics. The third part tries to integrate the argument of Quraish Shihab with the hermeneutics concept of Heidegger and Habermas. This hermeneutical linkage analysis is divided into two points: The first point juxtaposes Shihab and Heidegger in existentialist philosophical analysis; while the second point juxtaposes Shihab and Habermas in an intersubjective communication analysis. As the result, as well as the argument of this paper, is that the religious thought of contemporary Indonesian exegete, M. Quraish Shihab, is relevant to the philosophical thoughts of contemporary philosophers, such as Heidegger and Habermas.

The paper is based on library research. The data obtained in this research are from library materials, such as books, journal articles, and audio-visual files. Two criteria in material selection are in consideration: a) the principle of recency; b) the principle of

4 Afrizal Nur, "M. Quraish Shihab dan Rasionalisasi Tafsir," Jurnal Ushuluddin XVIII, no. 1 (2012). 
relevance. 5 These two criteria are used in selecting various reference sources, both those related to the figures discussed in this study and those related to the theme of research on interreligious harmony. The theoretical framework of this research is critical discourse analysis. Discourse is understood as a complex set of relations including relations of communication between people who talk, write and in other ways communicate with each other. It also describes relations between concrete communicative events, such as conversations and newspaper articles. However, there are also relations between discourse and other such complex objects, such as physical world, persons, power relations and institutions, which are interconnected elements in social activity or praxis. ${ }^{6}$ The discourse produced by Quraish Shihab when he talks about inter-religious harmony in the television program, Lentera Hati, does not stand alone, but relates to the context of human life in general, especially with regard to religious diversity. The context surrounding the Quraish Shihab is the diversity of religions in Indonesia, where the social order must be arranged in such a way so that human life can be in harmony. By analyzing the relevance of Quraish Shihab's Quranic Exegesis on Interreligious Harmony with the Contemporary Western Hermeneutics, such as Heidegger and Habermas, it will appear that the diversity of views must be appreciated and well managed in social life.

\section{Quraish Shihab on Inter-Religious Harmony}

Quraish Shihab was born in South Sulawesi, 1944. In 1992, he was a Chancellor of IAIN Syarif Hidayatullah, Jakarta, after previously serving as Vice Rector for Academic Affairs. In 1998, he was appointed by President Soeharto as Minister of Religion of the Republic of Indonesia in the VII Development Cabinet. Quraish Shihab was a scholar-thinker who was very productive in producing written works. Academically, he is very consistent in his path; the study of Qur'an and its exegesis. Some of his works

\footnotetext{
${ }^{5}$ Nursapia Harahap, “Penelitian Kepustakaan,” Journal Iqra' 08, no. 01 (2014): 69 .

${ }^{6}$ Norman Fairclough, Critical Discourse Analysis: The Critical Study of Language (London: Routledge, 2013), 3.
} 
are as follows: (1) "Membumikan" Al-Qur'an: Fungsi dan Peran Wahyu dalam Kehidupan Masyarakat ${ }^{7}$; (2) Lentera Hati: Kisah dan Hikmah Kehidupan'; (3) Wawasan Al-Qur'an: Tafsir Maudhu'i atas Pelbagai Persoalan Umat'; (4) Mukjizat Al-Qur'an: Ditinjau dari Aspek Kebahasaan, Isyarat Ilmiah, dan Pemberitaan Gaib10; (5) Tafsir AlQur'an al-Karim: Tafsir atas Surah-surah Pendek Berdasarkan Urutan Turunnya Wahyu'11; (6) Ensiklopedia Al-Qur'an: Kajian Kosakata12; (7) Tafsir Al-Mishbah: Pesan, Kesan dan Keserasian Al-Qur'an ${ }^{13}$. By using various methods of interpretation in his works, such as maudū' (thematic) and tahlili (analytic), the style of Shihab's qur'anic interpretation can be categorized as societal style. It means that he tries to highlight actual social problems. The problems then answered by dialogue with Qur'an. He tries to show how Qur'an talks about these problems and what solutions Qur'an offers to them. This effort is to show that Qur'an is a guide for life and guidance for all humans. ${ }^{14}$

In the episode of Lentera Hati aired by Metro TV, Quraish Shihab as the main speaker elaborates the discourse of interreligious harmony comprehensively. ${ }^{15}$ The event was divided into

7 M. Quraish Shihab, "Membumikan" Al-Quran: Fungsi dan Peran Wabyu dalam Kehidupan Masyarakat (Bandung: Mizan, 1994).

8 M. Quraish Shihab, Lentera Hati: Kisah dan Hikmah Kehidupan (Bandung: Mizan, 1994).

${ }^{9}$ M. Quraish Shihab, Wawasan Al-Quran: Tafsir Maudhu'i Atas Pelbagai Persoalan Umat (Bandung: Mizan, 1997).

${ }^{10}$ M. Quraish Shihab, Mukjizat Al-Quran: Ditinjau dari Aspek Kebahasaan, Isyarat Ilmiah, dan Pemberitaan Gaib (Bandung: Mizan, 1997).

${ }^{11}$ M. Quraish Shihab, Tafsir Al-Qur'an al-Karim: Tafsir Atas Surah-Surah Pendek Berdasarkan Turunnya Wabyu (Bandung: Pustaka Hidayah, 1997).

${ }^{12}$ M. Quraish Shihab, Ensiklopedia Al-Qur'an: Kajian Kosakata (Jakarta: Lentera Hati, 2007).

${ }^{13}$ M. Quraish Shihab, Tafsir Al Mishbah: Pesan, Kesan dan Keserasian AlQur'an (Jakarta: Lentera Hati, 2002).

14 Muhammad Iqbal, "Metode Penafsiran Al-Qur'an M. Quraish Shihab," Journal Tsaqafab 6, no. 2 (2010); Atik Wartini, "Corak Penafsiran M. Quraish Shihab dalam Tafsir Al-Misbah," Hunafa: Jurnal Studia Islamika 11, no. 1 (2014).

15 Simpan Sehat, "Lentera Hati MetroTV - Kerukunan Antar Umat Beragama," last modified December 24, 2013, https://www.youtube.com/watch?v=BcrIrdUcV9c. 
two sessions: monologue and dialogue. In the monologue session, Quraish Shihab, as popular Indonesian qur'anic exegete, explored many qur'anic verses as well as Muhammad tradition related to inter-religious life.

Shihab said that according to Muslim's belief, God is Omnipotent. Does God have ability to make all mankind in one religion only? Yes, He does. If so, why do religious differences occur? Why are there Muslims, Christians, Hindus, Buddhas, various religions and many beliefs? It must be His will. It is the main principle that must be implanted in the hearts and minds of everyone who believes in God that God is Almighty. This principle is repeatedly written in the Qur'an:

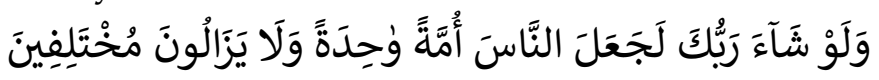

In his Tafsir al-Mishbah, Shihab describes this verse as follows: And if your Lord, O Muhammad, who has always been doing good and guiding you wills, of course He will make all human beings one, namely adhering to only one religion and submitting to Allah, just like the angels, but Allah does not want that, so that the human kind does not become one people. Allah gave them the freedom to sort and choose so that they always disagree, even though related to the main religious issues which should not be disputed (Qs. Hūd 11:118).16

How if God wanted to make all human beings in one religion only? Shihab argued: "One way God may do is repealing human ability to sort and choose. He will make humans like angels. However, God does not want it. Humans get freedom. They may select and learn their own religion. They may also know other religions. They may choose to be Muslims or other religion's adherents. Based on this consideration, all people should respect any choices taken by individual, because God gives humans freedom."

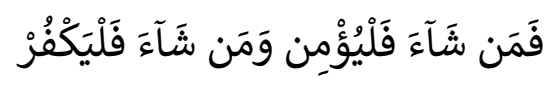

Shihab interpret this verse as follows: So, whoever among you, or other than you who wants to believe in what I am (Muhammad)

${ }^{16}$ M. Quraish Shihab, Tafsir Al Mishbah: Pesan, Kesan dan Keserasian AlQur'an. Volume: 6 (Jakarta: Lentera Hati, 2002), 374. 
conveying, let him believe, the benefits will return to himself, and whoever among you and other than you want to disbelieve and reject Allah's messages, then let him be an infidel, no matter how rich and high his social position may be (Qs. al-Kahf 18: 29). ${ }^{17}$

Humans are responsible for their own choice. It is one of the principles that every religious person must realize. Shihab asserted that humans should not be more enthusiastic than God. God has given humans freedom. Humans should also give similar freedom to the others.

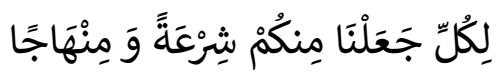

Interpreting this verse, Shihab said that for each people, namely groups who have the same time, or race or other similarities among you, $\mathrm{O}$ mankind, We give rules which are the source to eternal happiness and the bright path to that source (Qs. al-Mä'idah 5:48). ${ }^{18}$

How does God give a law and an open way? Shihab gives a description as follow: God, Allah, has sent messengers everywhere to give warnings and good news. Qur'an states:

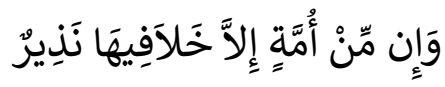

And there never was a people, without a warner having lived among them (in the past) (Qs. Fātir 35:24). Based on this verse, Shihab asserted that there were warners In Indonesia. The prophets are numerous, while the last prophet according to Muslim's belief is Prophet Muhammad. These prophets came with their teachings. After they left, their teachings were developed by their followers as new problems arose. Sometimes, the development was in accordance with the principles of teachings. But on the other hand, there was also an inappropriate development. God gives each one the system set by God through the development activities of the followers. Some say: It is my law; It is my method.Muslims have particular law and method. Christians have particular law and method. Hindus also

${ }^{17}$ M. Quraish Shihab, Tafsir Al Mishbah: Pesan, Kesan dan Keserasian AlQur'an. Volume: 8 (Jakarta: Lentera Hati, 2002), 52.

${ }_{18}$ M. Quraish Shihab, Tafsir Al Mishbah: Pesan, Kesan dan Keserasian AlQur'an. Volume: 3 (Jakarta: Lentera Hati, 2002), 111. 
have the same pattern. Each one may follow its respective method. Qur'an states:

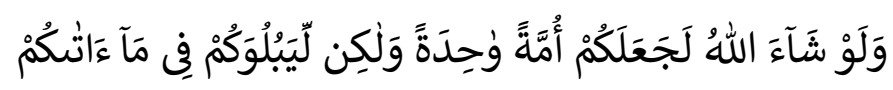

Shihab explained this verse in his work Tafsir Al-Mishab as follow: If Allah willed, surely $\mathrm{He}$ will make you, $\mathrm{O}$ people of Moses and Jesus, Muhammad's people and other people before that, one people only, that is by instinctively uniting your opinion and not giving you the ability to choose, but He, Allah does not want that. Because, He wants to test you, that is, treat you to the treatment of people who want to test what He has given you, both concerning the law and other potentials, in line with the differences in potential and His grace to each (Qs. al-Maidah $5: 48) \cdot{ }^{19}$

God sent the prophets, such as Noah, Moses, Isa and Muhammad. The prophets had given religious teachings to humankind. Humans should follow and develop the prophets' commands. God indeed tested humans whether they follow or deny what they have developed.

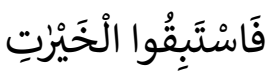

Based on this verse (Qs. al-Mä'idah 5:48), Shihab then talked about the principal of God's teaching, that all religious people are in the race in virtues: Muslims are in that kind of racing. So do Christians, Buddhis, Hindus, and Jews. If they can do the virtues together, they should do it.

Exploring the message of a hadith, Shihab said: "One of greatest sins is a person insulting his father. It did not make sense to the companions of the prophet. How does someone insult his father? The companions asked. The prophet replied: Someone cursed a father of another person. As the result the person replied cursing his father. Therefore, religion prohibits cursing other people's parents; reviling other people's prophet; and, insulting other people's teachings, because it can invite replies insulting."

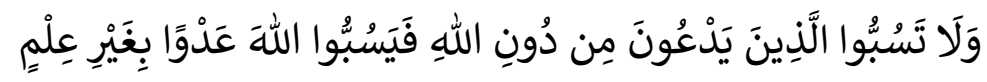

${ }^{19}$ Ibid., 111-112. 
According to Shihab, this verse is only addressed to the community of Muslims: And do not, O Muslims, curse idols that they worship besides Allah, because if you curse them then as a result, they will also scold Allah by transgressing or hastily without thinking and knowledge (Qs. al- $A n^{\prime} \bar{a} m$ 6: 108). ${ }^{20}$

Muslims should never revile, curse, and insult other people's God. Muslims should not blame the religious teachings in front of the adherents. Muslims should not bother them. If so, they will also insult Allah, Muslim's God. They will curse Muslim's teaching. The Qur'an states:

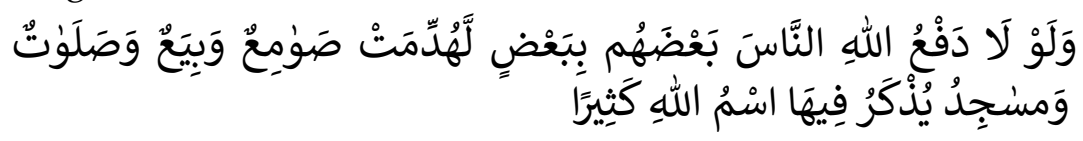

Did not God check one set of people by means of another, there would surely have been pulled down monasteries, churches, synagogues, and mosques, in which the name of God is commemorated in abundant measure (Qs. al-Hajj 22:40). Based on this verse, Shihab said that the enemies of religion will destroy the places of worship. Therefore, religious people should work together. They are obliged to keep, for example, a church. Because if someone able to destroy it, someone else may destroy a mosque. It is a religious teaching written in the Qur'an. If someone wants to be respected, he or she should respect others as well. These are principles of harmony taught in Islam.

Furthermore, Shihab relates the concept of 'adl and ihsān in the contexts of inter-religious relation. 'Adl or justice is giving one's rights as they are. Iḥsān moves beyond the rights. In $i h s \bar{a} n$, someone takes only part of his or her rights, and gives more the rights of others.

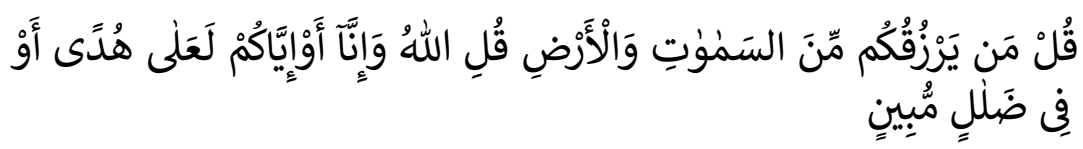

Based on this verse (Qs. Saba' 34:24), Shihab said: "What does it mean? Maybe I am right. Maybe you are right. Maybe I am

${ }^{20}$ M. Quraish Shihab, Tafsir Al Mishbab: Pesan, Kesan dan Keserasian AlQur'an. Volume: 4 (Jakarta: Lentera Hati, 2002), 242. 
wrong. Maybe you are wrong. That is social life. Do not accusing: you will definitely go to hell."

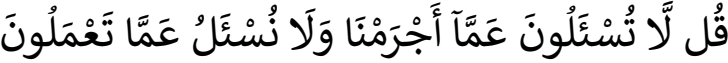

Say: "You will not be questioned, that is, you will be held accountable for the sins we have committed if you consider our Islam is a sin and we will not be asked about what you are doing and will do." (Qs. Saba' 34:25). ${ }^{21}$

$$
\text { قُلْ يَجْمَعُ بَيْنَنَا رَبِنَّا ثُمَّ يَفْتَحُ بَيْنَا بِالْحَقِّ وَهُوَ الْفَتَّاحُ الْعَلِيمُ }
$$

Say: "Our Lord, that is Allah, will gather us all together, then He will make decisions between us fairly and correctly. And He is the All-decision-Giver, All-Knowing." (Qs. Saba' 34:26). ${ }^{22}$

Shihab asserted that anyone should not be more enthusiastic than God. God has given humans freedom. People should find a common ground among them, that is by no disputing the truth and fault in the context of social life. Doing this concept, they will live in harmony and peace. That is, Shihab said, the principles of harmony in the teachings of Islam.

What Shihab explained about interreligious harmony at the Lentera Hati is in line with what he expressed in several of his works on similar topics. In his work "Membumikan" Al-Quran, Shihab states that by exploring religious teachings, leaving blind fanaticism, and based on reality, a path of coexistence and harmony can be formulated. Aren't monotheistic religions with the teachings of One Godhead essentially embracing universalism? It is God Almighty who created all human beings. All humans come from one lineage, regardless of religion, nationality or race. ${ }^{23}$

In his work Wawasan Al-Qur'an, Shihab linked harmony and democracy. He stated that Islam comes not only to maintain its existence as a religion, but also to recognize the existence of other religions, and to give them the right to live side by side while respecting the adherents of other religions. God has given freedom to humans to choose for themselves the way they think is good,

${ }^{21}$ M. Quraish Shihab, Tafsir Al Mishbah: Pesan, Kesan dan Keserasian AlQur'an. Volume: 11 (Jakarta: Lentera Hati, 2002), 380.

22 Ibid., 382.

23 Shihab, "Membumikan" Al-Quran, 219. 
and to express their opinions clearly and responsibly. It can be concluded that freedom of opinion, including freedom of choice of religion, is a right that is bestowed by God on every human being. What Qur'an says is the seeds of democracy. ${ }^{24}$

The Shihab's explanation about interreligious harmony above may and should be placed in the Indonesian context. It is very clear that the correlation of the text and context is very close. Indonesia is a country inhabited by followers of various religions. World religions live and develop in Indonesia, such as Islam, Catholicism, Protestantism, Hinduism, Buddhism and Confucianism. Furthermore, there are also many local belief systems in Indonesia that co-exist with adherents of world religions. These local beliefs even existed in Indonesia before the world's major religions came to the archipelago. ${ }^{25}$ In facing this diversity, the founding fathers of the Indonesian nation proclaimed the motto of unity in diversity. The motto of Bhinneka Tunggal Ika is really a great example from Indonesia how people from different communities, ethnic groups, cultures and religions are able to unite, communicate and act together to create a better life. In my view, Bhinneka Tunggal Ika is the bond of Indonesian people. Although we come from different perspectives, we can live under the same umbrella. Indonesian Muslims, Hindus, Buddhist, Christians and many other spiritual sects are tied together. ${ }^{26}$

\section{The Facticital Hermeneutics of Heidegger and The Critical Hermeneutics of Habermas}

Martin Heidegger (1889-1976) was a pioneering figure of philosophical hermeneutics. He changed the direction of hermeneutics initiated by Schleiermacher and Dilthey. There are two major themes discussed by Heidegger in philosophical

24 Shihab, Wawasan Al-Quran, 379-380.

25 Abdulloh Fuadi, "Menelisik Akar Multikulturalisme," in Pendidikan Multikultural Dalam Bingkai Horizon Keilmuan UIN Mataram, ed. Mukhlis (Mataram: Sanabil, 2020), 13.

26 Abdulloh Fuadi, "Bhinneka Tunggal Ika: The Contribution of Indonesian Islam to the Development of Common Ground in Interfaith Dialogue," in Proceeding Annual International Conference on Islamic Studies (AICIS) XIII (Mataram, 2013), 1633-1653. 
hermeneutics: being and language. This paper will only discuss the first theme. The concept of being was his fundamental question and attention throughout his magnum opus work. ${ }^{27}$ Hardiman said that the core thought of this work is about daily mystique. ${ }^{28}$ Heidegger also discussed deeply on language. ${ }^{29}$

The theme of being is triggered by phenomenological approach. Heidegger used many terms, such as Dasein or Beingthere, as well as Being-in-the-world, ${ }^{30}$ referring to human fate, as his disapproval abstraction of the traditional view of duality: subject and object, in understanding. For Heidegger, in a state of 'just thrown away', human, as Dasein, is intertwined closely between subject and object. ${ }^{31}$ That experience of 'just being' is referred by Heidegger to facticity (faktizitat). ${ }^{32}$

The hermeneutics of Heidegger is called facticital hermeneutics because, for Heidegger, understanding (verstehen) is

${ }^{27}$ Martin Heidegger, Being and Time: A Translation of Sein Und Zeit, ed. Dennis J. Schmidt, trans. Joan Stambaugh (Albany: State University of New York Press, 1996), 5.

${ }^{28}$ F. Budi Hardiman, Heidegger Dan Mistik Keseharian: Suatu Pengantar Menuju Sein Und Zeit (Jakarta: Kepustakaan Populer Gramedia, 2008), 2.

${ }^{29}$ Martin Heidegger, On the Way to Language, trans. Peter D. Hertz (New York: Harper \& Row, 1971); Martin Heidegger, Poetry, Language, Thought, trans. Albert Hofstadter (New York: Harper \& Row, 1971).

${ }^{30}$ It is different from other entities in which the way of their being is Being-within-the-world. Dasein is being-in-the-world through three ways: Being-with-others or Mitsein, Being-alongside-things or Sein-bei, and Beingone's-self or Selbstein. Heidegger, Being and Time: A Translation of Sein Und Zeit, 53; See Further: Yeremias Jena, "Martin Heidegger Mengenai Mengada Secara Otentik Dan Relevansinya Bagi Pelayanan Kesehatan," Journal Melintas 31, no. 2 (2015): 109-112; Sindung Tjahyadi, "Manusia Dan Historisitasnya Menurut Martin Heidegger," Journal Filsafat 18, no. 1 (2008).

31 Nasaiy Aziz, "Manusia Sebagai Sabyek Dan Obyek Dalam Filsafat Existentialism Martin Heidegger - Kajian Dari Segi Karakteristik Dan Pola Pikir Yang Dikembangkan," Journal Substantia 15, no. 2 (2013); Fadhillah, "Hakikat Hidup Manusia Dalam Konsep Ruang Dan Waktu Menurut Filsafat Eksistensialisme Heidegger," Journal Madani II (n.d.): 2009.

32 F. Budi Hardiman, Seni Memahami - Hermenentik Dari Schleiermacher Sampai Derrida (Yogyakarta: Kanisius, 2015), 107. 
not a cognitive act, 33 but the act of primordial from Dasein which is pre-cognitive. The facticital hermeneutics is in charge of interpreting such primordial actions by allowing understanding as facticity to manifest itself. This is where the influence of phenomenology is seen in Heidegger's thought. ${ }^{34}$ Understanding is a whole disposition in one's way of life, which is then called prestructure of understanding or presupposition. It is formed from the totality of Dasein's involvement in the practices of a life. It is non-thematic, pre-predicative, and non-verbal. Dasein is really involved in the practices. From this involvement, understanding is growing. Thus, humans are hermeneutical beings. An interpretation is directed by the unconscious pre-cognitive disposition. Within each interpretation, there is pre-structure of understanding which is directing the interpretation. This explanation shows that understanding implicitly precedes interpretation. Interpretation is explicating an implicit understanding.

Due to the existence of pre-structure of understanding, interpretation thus involves three steps: 1 . Lifting to consciousness; 2. Clarification of meaning; 3. Displaying the invisible. In the first step, interpretation means connecting with the consciousness that is formed from the practice of everyday life. In the second step, interpretation means clarifying the meaning that comes from this consciousness. While in the third step, interpretation means to reveal something that is hidden. From this process, it is expected to emerge disclosure. The term Aletheia refers to this kind of disclosure. As facticity, interpreting always directs to the future because Dasein is temporal who is anticipating his own possibilities. Interpreting is projective. Pre-structure of understanding is thus having orientation to the future. Interpreting is revelation of meaning for the future and its new

33 The Heidegger's concept of thinking, see: Martin Heidegger, What Is Called Thinking?, ed. Ruth Nanda Anshen, trans. Fred D. Wieck and J. Glenn Gray (New York: Harper \& Row, 1968).

${ }^{34}$ Martin Heidegger, Introduction to Phenomenological Research, trans. Daniel O. Dahlstrom (Bloomington: Indiana University Press, 2005); Martin Heidegger, The Basic Problems of Phenomenology, trans. Albert Hofstadter (Bloomington: Indiana University Press, 1982). 
possibilities. In this sense, the truth is not a correspondence between the meaning of the text and the reality, nor it is a coherence within the text itself, but unfolding meaning that occurs in existential encounter between the reader and the text. ${ }^{35}$

Jurgen Habermas (b.1929) focuses on the problem of intersubjective communication in public sphere. ${ }^{36}$ The Habermas's thoughts criticize and fulfill the lack of previous theories. Understanding may be controlled by the processes of power. Habermas also criticized the claim of the universality of ordinary hermeneutics, led by Heidegger and his disciple Gadamer, by pointing out the boundaries of ordinary hermeneutics on two things: the monologic language of the natural sciences and systematically distorted communication. ${ }^{37}$ In distorted communications, Habermas refers to two cases: first, psychopathological case; second, collective behavior case as a result of indoctrination. This Habermas's view is then referred to 'Critical Hermeneutics', where he became the most powerful and influential figure of the second generation of the Frankfurt tradition. $^{38}$ The tool of analysis used by Habermas in constructing his critical hermeneutics is Freud's psychoanalysis and Marx's ideological critique (domination and repression). ${ }^{39}$

The second case, collective behavior as a result of indoctrination, is more complicated than the first case. In this

35 Hardiman, Seni Memahami - Hermeneutik Dari Schleiermacher Sampai Derrida, 130.

36 Jürgen Habermas, The Structural Transformation of the Public Sphere: An Inquiry into a Category of Bourgeois Society, trans. Thomas Burger and Frederick Lawrence (Cambridge: Massachusetts Institute of Technology, 1989); See also: F. Budi Hardiman, Demokrasi Deliberatif: Menimbang "Negara Hukum" Dan "Ruang Publik" Dalam Teori Diskursus Jurgen Habermas (Yogyakarta: Kanisius, 2009), 13.

37 E. Sumaryono, Hermeneutik - Sebuah Metode Filsafat (Yogyakarta: Kanisius, 2003), 93.

38 Iwan, "Menelaah Teori Kritis Jurgen Habermas," Jurnal Edueksos III, no. 2 (2014).

39 Ahmad Atabik, "Memahami Konsep Hermeneutika Kritis Habermas," Journal Fikerah I, no. 2 (2013): 455-456; Ulumudin, "Jurgen Habermas Dan Hermeneutika Kritis - Sebuah Gerakan Evolusi Sosial," Journal Hunafa 3, no. 1 (2006): 77. 
second case, actors and speakers do understand their language and behavior, but their utterances and behavior are not produced by common sense, but by the effects of ideological indoctrination. It is called Falsches Bewubtsein or false consciousness. It is so-called 'systematically distorted communication'. It means that the communication of the actors has produced a system of misunderstanding that makes them unaware of mutual misunderstanding causing systematic distortion in their communication. They do not realize that their speech and behavior have been co-opted by a greater power, namely ideological indoctrination.

Furthermore, critical hermeneutics moves to communicative action. ${ }^{40}$ Communication opens the way for mutual understanding among actors. It is the central idea of Habermas's communicative theory of action. Consensus or collective agreement is the result of this kind of communication. The way to reach the consensus is that all actors have to have desire to do dialogue. The actor may propose ideas with arguments and evidence (Habermas terms it as the validity claims or claims of truth). ${ }^{41}$ In that way, he has to accept to be criticized. He has also to accept the truth coming from others. Thus, the subjective truth claim of each actor will meet common ground. The debate of rational argumentation will culminate to the most reasonable interpretation. This most reasonable interpretation should be accepted by all actors, because it tends to inter-subjective truth, namely agreement or consensus.

To reach a consensus on the claim of truth, there are four requirements that should be fulfilled. The truth should be: (1) understandable, (2) objective, (3) according to local norms, and (4) from the actor's experience and honesty. ${ }^{42}$ Related to the first

40 Jürgen Habermas, The Theory of Communicative Action. Volume1: Reason and The Rationalization of Society, trans. Thomas McCarthy (Boston: Beacon Press, 1984); Jürgen Habermas, The Theory of Communicative Action. Volume 2. Lifeworld and System: A Critique of Functionalist Reason, trans. Thomas McCarthy (Boston: Beacon Press, 1987).

41 Jürgen Habermas, Communication and the Evolution of Society, trans. Thomas McCarthy (Boston: Beacon Press, 1979), 2.

42 Ahmad Abrori, "Refleksi Teori Kritis Jurgen Habermas Atas Konsesus Simbolik Perda Syariah,” Journal Abkam XVI, no. 1 (2016): 75. 
aspect, the truth in the consensus must be understood by all people involved in it. The second aspect is that the truth in consensus must be objective and factual universal, not subjective. The third aspect is that the truth in consensus must be in accordance with the norms and values that apply to the local area. This is to ensure that consensus reflects local wisdom. The fourth aspect is that the truth in consensus is not only derived from the shared experience of all people involved in it, but also related to their honesty.

\section{The Relevance: Stringing Network of Meaning}

In this section, the Quraish Shihab's exegesis on inter-religious harmony, and the hermeneutics framework of Heidegger and Habermas, are attempted to be intertwined. The relevance of Quraish Shihab's and Heidegger's perspectives result in analysis of existentialist philosophy, while the relevance of Quraish Shihab's and Habermas's perspectives result in analysis of intersubjective communication.

\section{The Analysis of Existentialist Philosophy}

The relevance of Quraish Shihab's and Heidegger's perspectives lies in their respective descriptions of human individuality. Quraish Shihab describes the freedom that each individual has to live according to what he/she wants, including about choosing to embrace a religion. On the other hand, Heidegger also describes human individuality where each person interprets his existence as a human through a different prestructure understanding for each individual.

Quraish Shihab asserted that if God wanted, He made all human beings in one religion only. One way He could do is by repealing human ability to sort and choose. He would make humans like angels. But God does not want it as stated in the Qur'an chapter Hīd 11:118 and chapter al-Mā'idah 5:48. Everyone is thus given a freedom to understand and interpret life, which then continue on the freedom of choosing a religious identity.

Furthermore, based on the Qur'an chapter Maryām 19:95, Quraish Shihab affirms the individuality of responsibility. Every human who lived since the prophet Adam until the last day, 
during his adulthood, and has known the teachings conveyed by the Prophet, will be held responsibility. Every human bear responsibility for his/her choice. Humans come to God individually.

Concerning the nature of individuality, Heidegger said that understanding religion is different from knowing theology. Theology is as a technic. It is cognitive, not existential. Understanding religion is an existential way based on particular religion. Each individual life based on the lifestyle of his/her religion. It is more primordial than the articulated teachings of faith, such as theology.

Based on Heidegger's thought, choosing a religious identity is thus not related to cognitive. As Dasein who is 'thrown away' and 'being-in-the-world', human is intertwined closely between subject and object. The abstraction of duality collapsed. The totality of Dasein's involvement in the practices of life shapes pre-structure of understanding or presupposition, which in turn drives people to interpret the text. One of these 'texts' is selection of religious identity.

Cognitively, if a person has known the categorization of A or $\mathrm{B}$, he can identify and choose between the two. But it is not so with the selection of religious identity. The issue of religion is not solely related to cognitive matters. It is not surprising if someone who is expert in the field of a particular religion, but he/she is not a follower of that religion. There are many Christologists but they are not followers of Christianity. There are many Islamologists but they are not Muslims. Understanding religion, again, is not same as knowing theology. Heidegger asserted it. On this issue, Quraish Shihab also asserts that every individual is given a freedom to understand and interpret life, including the freedom to sort and choose religious identity.

Many people are not in the position of choosing their religious identity. They get it as heritage identity. This background influences people's way of thinking. The practices of religious life form a certain presupposition that tends to a certain direction. It is the cause that someone interprets life in Islamic, Christian, Jewish, Buddhist, Hindu, Confucian, or any other belief system, depends on the pre-structure of understanding of each one. 
In a broader scale, each person will be given same respects despite of different articulation. Every human will be viewed as an autonomous individual. Each articulation will be judged based on the presupposition that is formed from the totality of human involvement in practices of life he/she lived. Any form of practices is legitimate, because human is Dasein thrown away into the world, without asking and expecting previously.

On this issue, the hermeneutics of Heidegger teaches that every human should be viewed as a concrete entity bringing respective presupposition. It is different from positivistic logic that tends to duality framework, subject and object, causing a response to another as an abstract entity. Related to the interpretation of texts, both written and unwritten, the hermeneutics of Heidegger more appreciates interpreters with their result of interpretation, whatever the level of shallowness and deepness. This right is based on the thought that Dasein is temporal, and therefore understanding is also evolving.

Along with the temporality of Dasein, interpretation is therefore indeed never stopped. The truth in interpretation is not identified as a constancy. The truth in interpretation will continue to expand following the temporality of Dasein. For human, the truth is assumed as a continuously widespread understanding without limit. Reality is an endless possibility, which reveals itself constantly. One should not worry on the objectivity of his/her interpretation, because the hermeneutics does not hunt objectivity but deepness. When someone interprets, the result of the interpretation in a particular period is not assumed as an absolute truth. A similar text might be interpreted wider than previous in accordance with the temporality of one's existence.

In line with above explanation, Shihab emphasized the importance of the word fardan (alone) in Qur'an chapter Maryām verse 95. God asserts that everyone has respective responsibility on what he/she has done. However, God will see humans with justice in accordance with the respective presuppositions. God would not only pay attention to the articulation, but also to how the articulation is constructed. Such thing lies on the presupposition formed from the totality of one's involvement in 
practices of life, causing the growing of understanding as an anticipation of any possibilities.

\section{The Analysis of Inter-subjective Communication}

The relevance of Quraish Shihab's and Habermas's perspectives lies in their respective descriptions of communication among different people in the effort to live in harmony. Quraish Shihab talks about how different religious people may and should live together, while Habermas talks about communicative action in public sphere among different actors to reach a consensus or agreement to live in harmony.

In his speech, Quraish Shihab said that Muslims should give freedom to others to choose their religious identity. Do not be more enthusiastic than God, he asserted. Each religious person should in a race of virtues, as stated in the Qur'an chapter alMá'idah 5:48. Quraish Shihab also reminded the ban on hate speech and attitude to other religions, as in Qur'an chapter alAn'âm 6: 108 and chapter al-Hajj 22:40. Cooperating in social life should be submitted first. Shihab said: maybe you are right, maybe I am right. Maybe you are wrong, maybe I am wrong. The best thing to be done is looking for common ground among religious communities. The issue of truth and error in the context of social life in inter-religious relation should not be asked. In this case, Shihab quotes Qur'an chapter Saba' 34: 24-26.

The hermeneutics of Habermas is important in inter-religious communication. Habermas shows that this kind of communication could not be applied in two spheres: monologic language of natural sciences and distorted abnormal text. Abnormal text is not understood even by its own speaker. There are two cases of abnormal text: psychopathology and collective behavior as a result of indoctrination. The second case should get more attention, because it is related to religious doctrine. The important contribution of Habermas hermeneutics is that there could be a special interest in any religious text which may not be realized by its author or speaker. The actors or speakers seem to understand their language and behavior, but actually it is not derived from common sense, but from the effect of ideological indoctrination. It is then called a false consciousness. 
The concrete examples of abnormal text in the field of religious indoctrination are the texts by terrorists, suicide bombings actors, or radical fundamentalists. The hermeneutics of Habermas does not assume that the texts as a truth because it is abnormal texts built on ideological indoctrination, not common sense. The hermeneutics of Habermas always suspects that every text definitely have interests. There is a hidden power in it which is not realized by the speaker. What can be learned from Habermas is to not always believe in speech or behavior of each individual. The speech or behavior is maybe an abnormal 'text'. This caution will raise awareness in order to get the truth.

When the actors meet each other in the public sphere, the importance of another framework of Habermas' hermeneutics would be visible: managing the best way in inter-subjective communication. If it is not managed properly, the public sphere may be messy, because each subject may claim his/her own truth and accuse that the truth of others formed due to indoctrination of certain presupposition. The contribution of Habermas' hermeneutics is on the idea of communicative action which paved the way for actors to reach a consensus or agreement. The subjective truth claim of each actor will meet common ground. The debate of rational argumentation will culminate in the most reasonable interpretation accepted by all actors. It is called inter-subjective truth, which is togetherness in agreement, consensus or understanding.

This consensus will ensure and guarantee the harmony of social life. On one hand, each subject will aware of his/her uniqueness and hence valid and recognized. On the other hand, when communicating with others, he/she will not force his/her own truth, but communicate with them to get a certain consensus. Is the practice of consensus has been done in daily life? Yes. However, the main contribution of this hermeneutics is that communication should be done among the subjects (intersubjective). Maybe the communication that has been occurred in public sphere is still assuming the relation between subject and object. The result of this kind of communication is victimization. It could be that someone accepts consensus due to forced. He acts as an object entity in the process of achieving consensus. 
If the thought of Habermas is drawn into the context of interreligious harmony, each religious person should see a partner from another religion as a subject entity that has sovereignty of thinking. Inter-religious cooperation in society requires an appreciation of egalitarianism, regarding each other as an autonomous concrete entity. It could be that any tensions among religious communities over past years is due to the positivistic communication patterns, assuming the partner as abstract objects. The example of this abstraction is someone assesses another with certain assumptions based only on his/her religious identity. On the other hand, the assumptions are the result of the accumulation of information that has been distorted. In such a way, the tension and suspicion inevitably continue.

When the partner is positioned as a subject entity, the religious identity is only surface information. The whole self of the partner can be unveiled by intense and continuous communication. During the process of communication, the concrete and unique self-reveals. The self which is formed from the complexity of life will be presented. The selection of any religious identity would be appreciated. From this atmosphere of communication, the interreligious harmony will appear. The result is an elegant and sympathetic cooperation will occur among different religious identity.

The most difficult to do is certainly getting consensus in social life. Indoctrination, as mentioned by Habermas, may happen to anyone. The case of terrorism and suicide bombings are merely examples which may actually be embedded in other forms of indoctrination. Therefore, it cannot be ignored other kinds of indoctrination, such as political indoctrination, mass media indoctrination, social media indoctrination, and even educational institutions indoctrination. With so many forms of indoctrination, the demand remains on intersubjective communication in order to achieve better consensus in public life, particularly in establishing inter-religious harmony.

In line with above explanation, Shihab emphasized the importance of finding a common ground among humans, that is by no disputing the truth and fault in the context of social life. The concept of living in harmony and peace is one of Islamic principles 
teaching. Furthermore, Shihab asserted that anyone should not be more enthusiastic than God. The concept of indoctrination by Habermas is in the same way of what Shihab said.

\section{Conclusion}

The paper has shown the relevance in the form of stringing network of meaning expressed by Quraish Shihab as he talked about inter-religious harmony in a television program, Lentera Hati, and written in some of his works, with the hermeneutics concept of Heidegger and Habermas. Therefore, the above description of existentialist philosophical analysis and intersubjective communication analysis confirmed that the religious thought of contemporary Indonesian exegete, M. Quraish Shihab, is relevant to the philosophical thoughts of contemporary philosophers, such as Heidegger and Habermas. However, it is undeniable that the recent issues show the complexity of problems related to inter-religious harmony, especially when it comes to political issues. The elegant consensus, therefore, should be pursued continuously.

\section{References}

Abrori, Ahmad. "Refleksi Teori Kritis Jurgen Habermas Atas Konsesus Simbolik Perda Syariah." Journal Ahkam XVI, no. 1 (2016).

Atabik, Ahmad. "Memahami Konsep Hermeneutika Kritis Habermas." Journal Fikrah I, no. 2 (2013).

Aziz, Nasaiy. "Manusia Sebagai Sabyek dan Obyek dalam Filsafat Existentialism Martin Heidegger - Kajian dari Segi Karakteristik dan Pola Pikir Yang Dikembangkan." Journal Substantia 15, no. 2 (2013).

Banawiratma, J.B. Dialog Antarumat Beragama - Gagasan dan Praktik di Indonesia. Bandung: Mizan, 2010.

Cholil, Moh. "Relevansi Pemikiran Tafsir Jihad M. Quraish Shihab dalam Tafsir al-Misbah." Maraji': Jurnal Studi Keislaman 1, no. 2 (2015). 
Fadhillah. "Hakikat Hidup Manusia dalam Konsep Ruang dan Waktu Menurut Filsafat Eksistensialisme Heidegger." Journal Madani II (n.d.): 2009.

Fairclough, Norman. Critical Discourse Analysis: The Critical Study of Language. London: Routledge, 2013.

Fuadi, Abdulloh. "Bhinneka Tunggal Ika: The Contribution of Indonesian Islam to the Development of Common Ground in Interfaith Dialogue." In Proceeding Annual International Conference on Islamic Studies (AICIS) XIII, 1633-1653. Mataram, 2013.

- - . "Menelisik Akar Multikulturalisme." In Pendidikan Multikultural dalam Bingkai Horizon Keilmuan UIN Mataram, edited by Mukhlis, 1-53. Mataram: Sanabil, 2020.

Habermas, Jürgen. Communication and the Evolution of Society. Translated by Thomas McCarthy. Boston: Beacon Press, 1979.

- - - . The Structural Transformation of the Public Sphere: An Inquiry into a Category of Bourgeois Society. Translated by Thomas Burger and Frederick Lawrence. Cambridge: Massachusetts Institute of Technology, 1989.

- - - . The Theory of Communicative Action. Volume 2. Lifeworld and System: A Critique of Functionalist Reason. Translated by Thomas McCarthy. Boston: Beacon Press, 1987.

- - - The Theory of Communicative Action. Volume1: Reason and The Rationalization of Society. Translated by Thomas McCarthy. Boston: Beacon Press, 1984.

Harahap, Nursapia. “Penelitian Kepustakaan.” Journal Iqra' 08, no. 01 (2014).

Hardiman, F. Budi. Demokrasi Deliberatif: Menimbang "Negara Hukum" dan "Ruang Publik" dalam Teori Diskursus Jurgen Habermas. Yogyakarta: Kanisius, 2009.

- - - Heidegger dan Mistik Keseharian: Suatu Pengantar Menuju

Sein Und Zeit. Jakarta: Kepustakaan Populer Gramedia, 2008.

- - - Seni Memahami - Hermeneutik dari Schleiermacher Sampai Derrida. Yogyakarta: Kanisius, 2015.

Heidegger, Martin. Being and Time: A Translation of Sein Und Zeit. Edited by Dennis J. Schmidt. Translated by Joan Stambaugh. Albany: State University of New York Press, 1996. 
- - - Introduction to Phenomenological Research. Translated by Daniel O. Dahlstrom. Bloomington: Indiana University Press, 2005.

- - - . On the Way to Language. Translated by Peter D. Hertz. New York: Harper \& Row, 1971.

- - - . Poetry, Language, Thought. Translated by Albert Hofstadter. New York: Harper \& Row, 1971.

- - - The Basic Problems of Phenomenology. Translated by Albert Hofstadter. Bloomington: Indiana University Press, 1982.

- - - What Is Called Thinking? Edited by Ruth Nanda Anshen.

Translated by Fred D. Wieck and J. Glenn Gray. New York: Harper \& Row, 1968.

Iqbal, Muhammad. "Metode Penafsiran Al-Qur'an M. Quraish Shihab." Journal Tsaqafah 6, no. 2 (2010).

Iwan. "Menelaah Teori Kritis Jurgen Habermas." Jurnal Edueksos III, no. 2 (2014).

Jena, Yeremias. "Martin Heidegger Mengenai Mengada Secara Otentik dan Relevansinya bagi Pelayanan Kesehatan." Journal Melintas 31, no. 2 (2015).

Nur, Afrizal. “M. Quraish Shihab dan Rasionalisasi Tafsir.” Jurnal Ushuluddin XVIII, no. 1 (2012).

Saifuddin. "Pergeseran Wacana Relasi Gender dalam Kajian Tafsir di Indonesia: Perbandingan Penafsiran 'Abd Al-Rauf Singkel dan M. Quraish Shihab." Mu'adalah: Jurnal Studi Gender dan Anak II, no. 2 (2014).

Sehat, Simpan. "Lentera Hati MetroTV - Kerukunan Antar Umat Beragama." Last modified December 24, 2013. https://www.youtube.com/watch?v=BcrIrdUcV9c.

Shihab, M. Quraish. Ensiklopedia Al-Qur'an: Kajian Kosakata. Jakarta: Lentera Hati, 2007.

- - - Lentera Hati: Kisah dan Hikmah Kehidupan. Bandung: Mizan, 1994.

---. "Membumikan" Al-Quran: Fungsi dan Peran Wahyu dalam Kehidupan Masyarakat. Bandung: Mizan, 1994.

- - - Mukjizat al-Quran: Ditinjau dari Aspek Kebahasaan, Isyarat Ilmiah, dan Pemberitaan Gaib. Bandung: Mizan, 1997.

- - - Tafsir Al Mishbah: Pesan, Kesan dan Keserasian Al-Qur'an. Jakarta: Lentera Hati, 2002. 
- - . Tafsir Al Mishbah: Pesan, Kesan dan Keserasian Al-Qur'an. Volume: 3. Jakarta: Lentera Hati, 2002.

- - - Tafsir Al Mishbah: Pesan, Kesan dan Keserasian Al-Qur'an. Volume: 4. Jakarta: Lentera Hati, 2002.

- - . Tafsir Al Mishbah: Pesan, Kesan dan Keserasian Al-Qur'an.

Volume: 6. Jakarta: Lentera Hati, 2002.

- - - Tafsir Al Mishbah: Pesan, Kesan dan Keserasian Al-Qur'an. Volume: 8. Jakarta: Lentera Hati, 2002.

- - . Tafsir Al Mishbah: Pesan, Kesan dan Keserasian Al-Qur'an. Volume: 11. Jakarta: Lentera Hati, 2002.

- - . Tafsir Al-Qur'an al-Karim: Tafsir Atas Surah-Surah Pendek Berdasarkan Turunnya Wahyu. Bandung: Pustaka Hidayah, 1997.

- - - Wawasan Al-Quran: Tafsir Maudhu'i Atas Pelbagai Persoalan Umat. Bandung: Mizan, 1997.

Sidiq, Umar. “Diskursus Makna Jilbab dalam Surat Al-Ahzab Ayat 59 Menurut Ibnu Kathir dan M. Quraish Shihab." Journal Kodifikasia 6, no. 1 (2012).

Sumaryono, E. Hermeneutik - Sebuah Metode Filsafat. Yogyakarta: Kanisius, 2003.

Swidler, Leonard, and Paul Mojzes. The Study of Religion in an Age of Global Dialogue. Philadelphia: Temple University Press, 2000.

Thohari, Chamim. "Konstruks Pemikiran Quraish Shihab Tentang Hukum Jilbab - Kajian Hermeneutika Kritis." Journal Salam 14, no. 1 (2011).

Tjahyadi, Sindung. "Manusia dan Historisitasnya menurut Martin Heidegger." Journal Filsafat 18, no. 1 (2008).

Ulumudin. "Jurgen Habermas dan Hermeneutika Kritis - Sebuah Gerakan Evolusi Sosial." Journal Hunafa 3, no. 1 (2006).

Wartini, Atik. "Corak Penafsiran M. Quraish Shihab dalam Tafsir Al-Misbah." Hunafa: Jurnal Studia Islamika 11, no. 1 (2014). 